\title{
Steder med appel
}

\section{af John Bale og Søren Nagbøl}

\section{Introduktion (John Bale)}

I sensommeren 1991 deltog jeg i et typisk nordisk „eksperimenterende" seminar i landsbyen Føns på Vestfyn i Danmark. Seminarets tema var "bevægelseskultur og bevægelsesrum", men det var mindre relevant i forhold til, at den uformelle atmosfære gav god grobund for udviklingen af personlige, såvel som akademiske relationer.

Blandt mange interessante mennesker mødte jeg Søren Nagbøl, en dansk stipendiat. Han arbejdede på Danmarks Højskole for Legemsøvelser, og jeg fandt hurtigt ud af, at han netop havde lavet en artikel om de miljømæssige konsekvenser af udvidelsen af det nationale fodboldstadion i København; en udvidelse af tribunen havde medført, at der kastedes længere skygger over det nærliggendebeboelsesområde, hvor han levede.

Jeg kunne identificere mig med hans analyse, ikke blot fordi forslag fra Arsenals fodboldklub havde en lignende indflydelse på beboerne nær Highbury Stadion i det nordlige London, men også fordi min egen forskning havde været rettet mod de lokale virkninger af fodboldstadioner i England og Wales. Vore metodiske tilgange til studiet af fodboldstadioner var meget forskellige. Min havde været baseret på velfærdsøkonomiske synsvinkler, mens hans havde været meget mere humanistisk orienteret.

Jeg opdagede hurtigt, at Søren i lige så højgrad var kunstner som videnskabsmand, især i kraft af hans betydelige interesse for arkitektur og hans dygtighed med et kamera.

I løbet af den idylliske uge i Føns udvekslede vi ideer og talte længe om fodboldstadioner og deres plads i det moderne byliv. Jeg var forundret over at opdage, at Søren aldrig havde været i England og foreslog ham, at han rådede bod herpå så hurtigt som muligt. Det var blevet klart for mig, at det engelske fodboldmiljø var forskelligt fra det danske; de typiske, pæne og rene, danske forstads-stadioner stod i modsætning til de rå engelske baner, som jeg kendte. Søren modtog med glæde min invitation til at vise ham et typisk udsnit af fodboldmiljøer $\mathrm{i}$ Nordvest-og Midtengland, samt Yorkshire.

Min danske gæst tilbragte en uge hos min familie og jeg i januar 1992. Hver dag tog vi fra mit hjem nær Crewe til nogle af de betydelige (og andre ikke så betydelige) fodboldbaner i England. Søren havde sit kamera med som trofast følgesvend, og han tog ca. 200 billeder under vore ture. Når vi kom hjem om aftenen, gik Søren op på sit værelse og skrev dagbog.

Et par måneder senere vendte jeg tilbage til Danmark, hvor vi så hans billeder og en tilfældig bemærkning om muligheden for at offentliggøre dem, førte os til seriøst at overveje at skrive en bog baseret på billederne og de tanker han havde gjort sig $\mathrm{i}$ forbindelse hermed.

Det følgende er resultatet heraf:

Ordene og billederne behøver ikke yderligere kommentarer, udover at de beskriver mere end blot en række bygninger og fodboldbaner; de giver en fornemmelse af sted og på mange måder opsummerer de nationens tilstand.

\section{Rejsen til England (Søren Nagbøl)}

Rejsen til England handler om mit første møde med England, og hvordan man oplever et fremmed land, når man kommer med fly; dumper ovenfra og ned og bliver budt indenfor i en landsby hos en kollega og hans familie. 


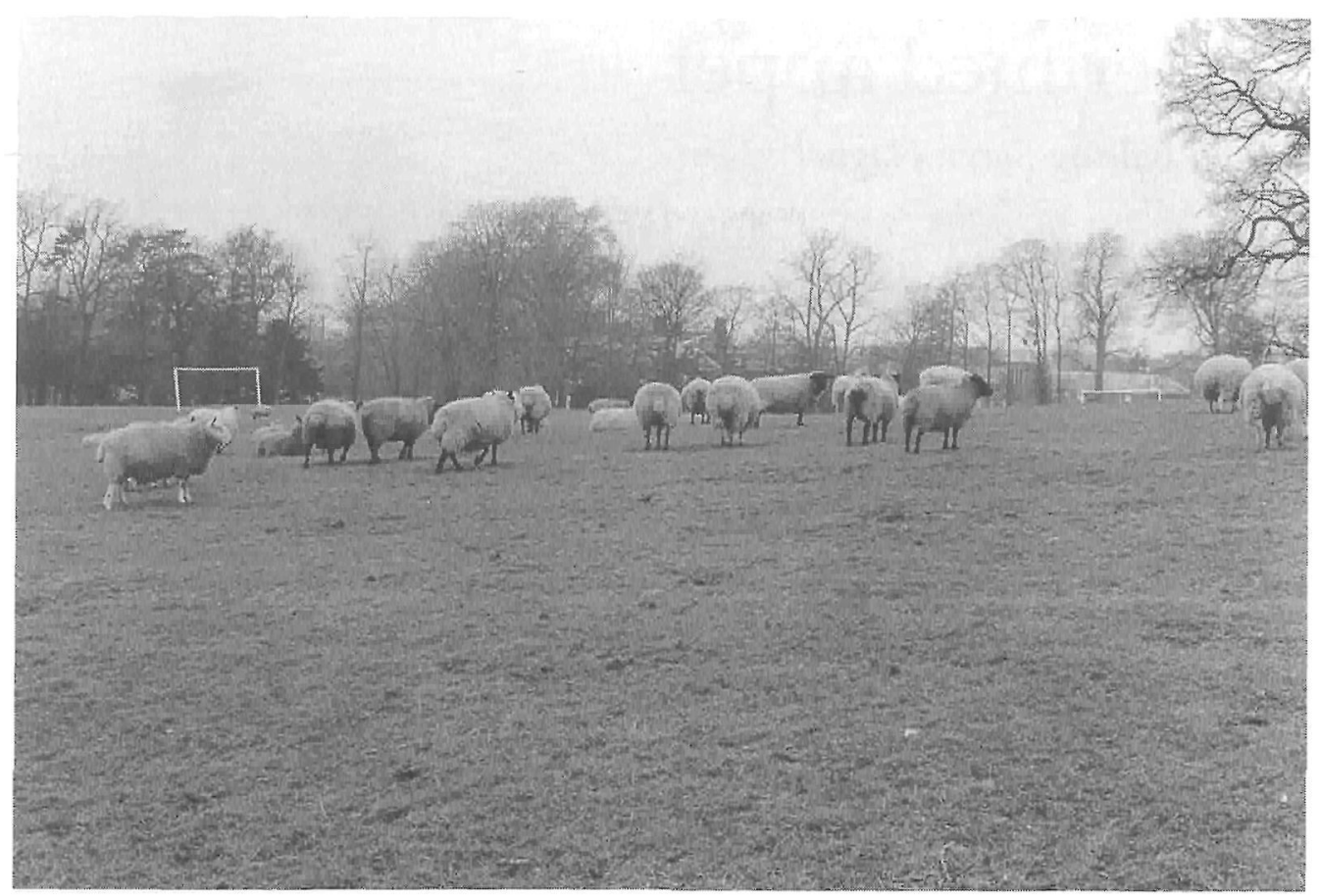

Det er en beretning i billeder og ord om en rejse gennem den centrale del af England sammen med John Bale. Januardisen, et ironisk mættet melankolsk møde med levende undertoner der varer fra d.11.1. - 19.1.92

Det handler om fodboldstadioner, deres omgivelser, udseende og atmosfære, traditioner-ne og myterne omkring dem. Stedernes poesi og erindring-hooliganisme - kulturel identitet og meget mere. Menneskene motorvejene og den strøm af biler, der truer med aldrig at ville holde op. Og kunsten at komme tæt på de forhold som drejer sig om cricket og fodbold set som en del af et landskab som ændre sig i takt med, at menneskenes forhold til at udøve og opleve sport gør det.

Hvad betyder disse forandringer for dem, der bliver indbe- og grebet af denne udvikling ? Det er det spørgsmål vi stiller.

\section{Betley}

Betley er en landsby, der ligger midt i England nær Crewe. Der er stort set lige langt, om du kører til Manchester, Liverpool eller Birmingham. Der i et nyt beboelseskvarter, lidt for sig selv bor min kollega og hans familie.

Betley og landskabet omkring den opfylder alle de forestillinger jeg har haft om England. Der ligger den traditionelle kirke i udkanten af byen op af en eng, som om den har gjort det i umindelige tider. Der ligger en selvfølgelig evighedsfølelse over stedet. Historien kan gå sin gang, jeg bliver liggende her, og opfylder mine forpligtelser overfor good old England. Deter signalet, den fremmede møder. Og det fylder en med ro, for man har følelsen af altid at have hørt til her.

Jeg går videre op af en markvej, der er omgivet af stendiger, de snor sig i vejens rytme. På den måde følges man op til et lille træhus på toppen af en eng. Som den mest selvfølgelige ting i verden ligger der en cricketbane, der er så grøn og stille, at du taber enhver uro.

Banen gror og ligger hen, og er så åben overfor bevægelser, at det er til at holde ud at væ-re alene. Græsset må gerne betrædes, men hunde skal holde sig fra banen.

Det er et sportslandskab, som er til at fatte for det er så rent og ligetil, at spillets 


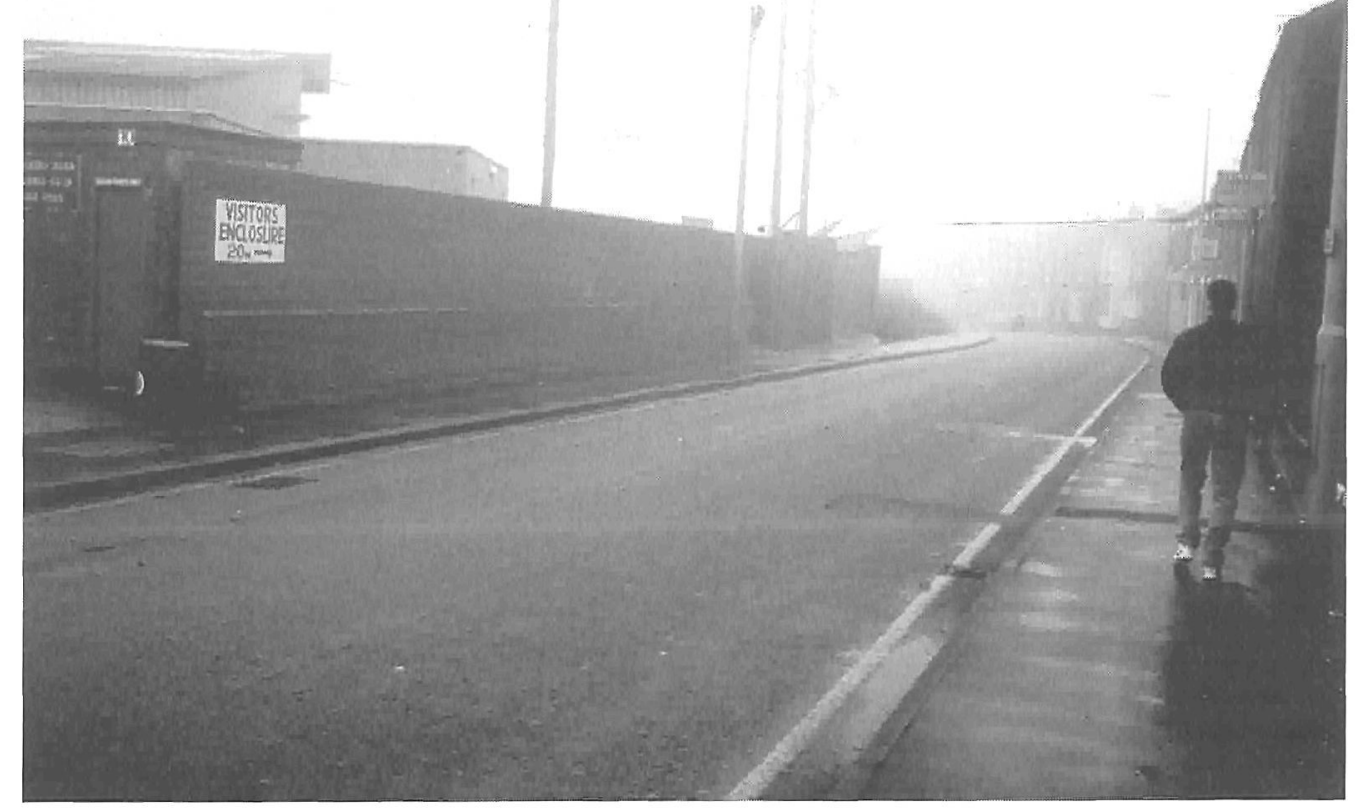

regler sætter sine egne spor. Hvor må det være befriende for alle parter at være her.

I januardisen kan man godt dufte forandringen til sensommerens frydefulde melankoli. Det letter at gå rundt i det våde græs med dug på skoene. I det fjerne skimtes fårene og to fodboldmål. De får går bare rundt og - spiser, bliver klippet, spiser og bliver klippet, giver mælk og bliver slagtet.

\section{Crew}

Søndag - the day after the game - kører vi til Crew. Det foregår i bil af landeveje, motorveje, mindre veje gennem øde industribebyggelser, ensomme transportveje, der fører til steder der føles forfaldne og forladte. Menneskenes spontanitet er for længst borte. Tilbagestår ensomme toetagers rækkehuse, gade op og gade ned.

Hovedgaden $i$ byen er lang og trist, der er en forretning med dagligvare, den evigt åbne fish and chips biks, et par eksotiske restauranter med indisk eller taiwansk betjening. Længere henne lidt bag om det hele, men klods op af det centrum, som man hele tiden søger, en rutebilstation. Omtåget gammel og beskidt. Krigen er lige holdt op, og man er ikke kommet igang igen. Sådan må det have set ud i fyrre år. Kullet og kraften som skulle bruges til starten af et nyt liv, slap op.

Her $\mathrm{i}$ en af gaderne med de endeløse rækker af rækkehuse ligger på den anden side af vejen - klods overfor der hvor man bor - Crew stadion.

Ved første øjekast ligner det en koncentrationslejr. Ved nærmere eftersyn et lille fæstningsanlæg. Ligegyldigt hvad det kaldes, det er svært at komme ud eller ind, hvis dem der bestemmer ikke ønsker det. Her kan nogen som man aldrig ser bestemme, om man er udenfor eller indenfor, hvordan og i hvilken rækkefølge. Her opdager man med det samme, hvad det vil sige at høre til, være hjemme - eller komme udefra som fremmed. Det første skilt vi støder på, da vi står ud af bilen er "Visitors 20 m" og en pil viser hen ad vejen, der er så grå og trist, at man skulle tro at den førte direkte til et fabriksanlæg, der var gået i stå. Fremtidsperspektivet er en uigennemsigtig dyne af vandpartikler, der er klamme. Smagen af kul, støbejern og hårdt arbejde bider sig fast i tågen. Usigtbarheden er tæt på. 


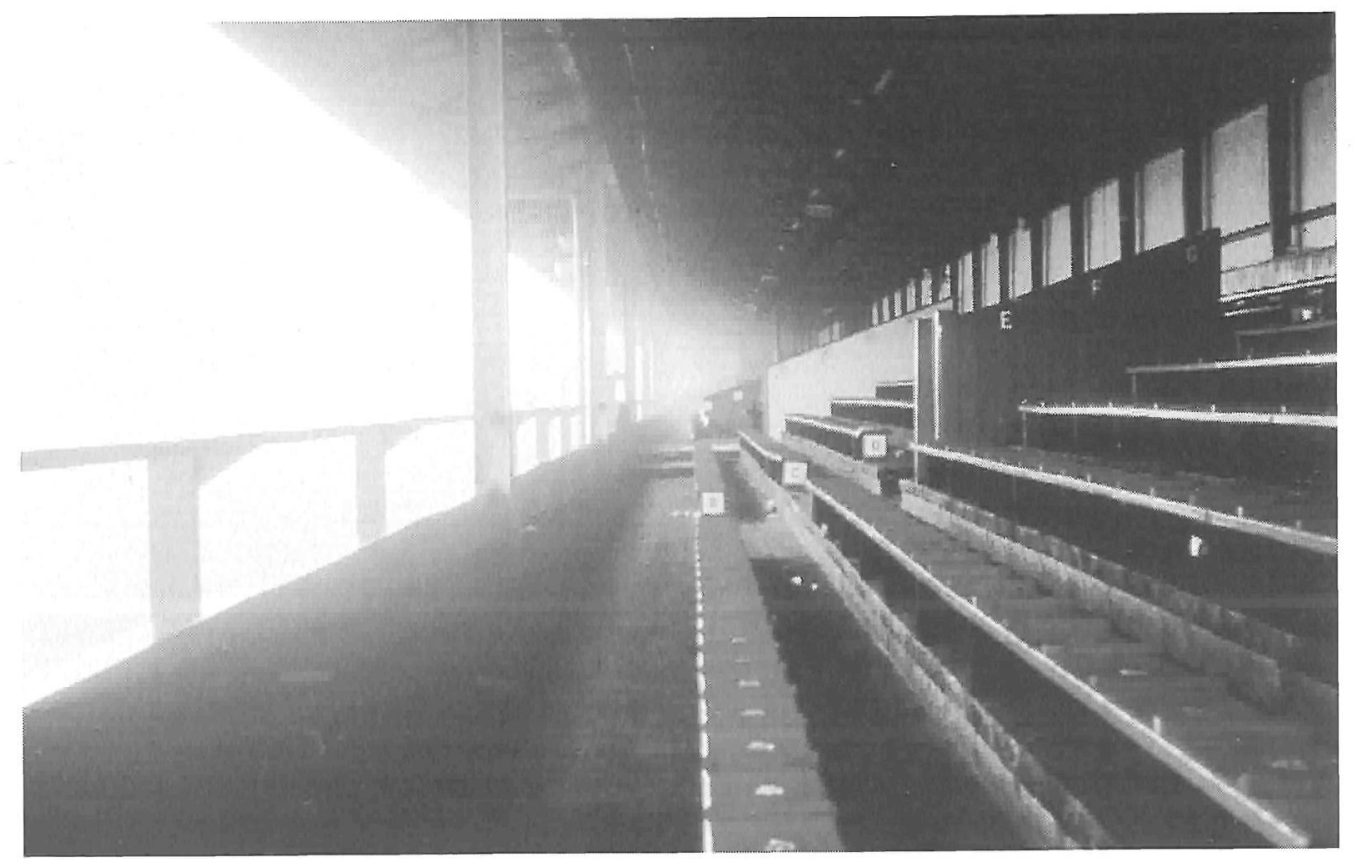

Indenfor er man delt op i etablerede og outsidere - de fremmede dem der er imod hjemmeholdet - er lukket ude fra spillet ved at være buret inde bag et hegn, der er som pigtråd for øjet.

Dem der er fra og for Crew kan indtage deres vante pladser, der hvor de er kommet år efter år, generation efter generation. En verden der står som den altid har stået, hvor befolkningen har kunnet sætte sine egne erindringsspor. I dette stadion er minderne fra årtiers lokalkampe tilstede, hver gang dem der har præget stedet er tilstede. Genkendelsen og minderne har man i fællesskabet selv stået for. De hører til her som deres arv til hinanden. Utallige besøg mødet med vennerne har sat sine spor, spor af tryghed og stabilitet." Det skal ingen tage fra os", siger indhegningen, banen pladserne, tribunen. Her kender man sin plads, man er så at sige groet til på stedet. Der er ikke stedfæstet nogen flygtighed, men derimod et sammenhold som er slående. Det er tilskuernes egen medvirken, som skaber deres plads på dette stadion, bag målet, på langsiden eller på bænkene under halvtaget. Der hvor man sidder, når man ikke gider eller kan stå op mere. Overlade dette til de evigt unge fans bag målet eller klyngen af vennerne på den billige langside., og trække sig tilbage på retrætepladsen for de trætte ben på de røde bænke, med et tæppe over de forslidte knæ.

På disse bænke hænger man sammen med de andre uden at være sat på plads. Bekvemmelighed er her alt andet end inventar, der lægger op til kuldegysninger, som f.eks. de moderne stadioners skåleformede plasticsæder.

Der skal derimod et godt helbred til for at være visitors. Hvilket billede man har af dem, når man ser deres placering, må være makabert. Det må være for de vilde unge bavianer, lærlinge ungarbejdere, fra mine og værftsindustrien, ellers måtte det være anderledes indrettet. De er buret inde og må optræde som rasende galninge for hegnet er en provokerende begrænsning for tilskuerne. Her kan fodboldspillet ikke længere fængsle, netop fordi man er spærret inde. Her kan man blive vidne til synsforstyrrelser, der bliver til skrig i tågen.

Crew hænger, som et sort og rødt gitter i erindringen, i det vi kører ud af den gade, vi kom fra. Vi er igen på vej ud i tågen, kulden og den uigennemskuelige strøm af biler på motorvejen. 


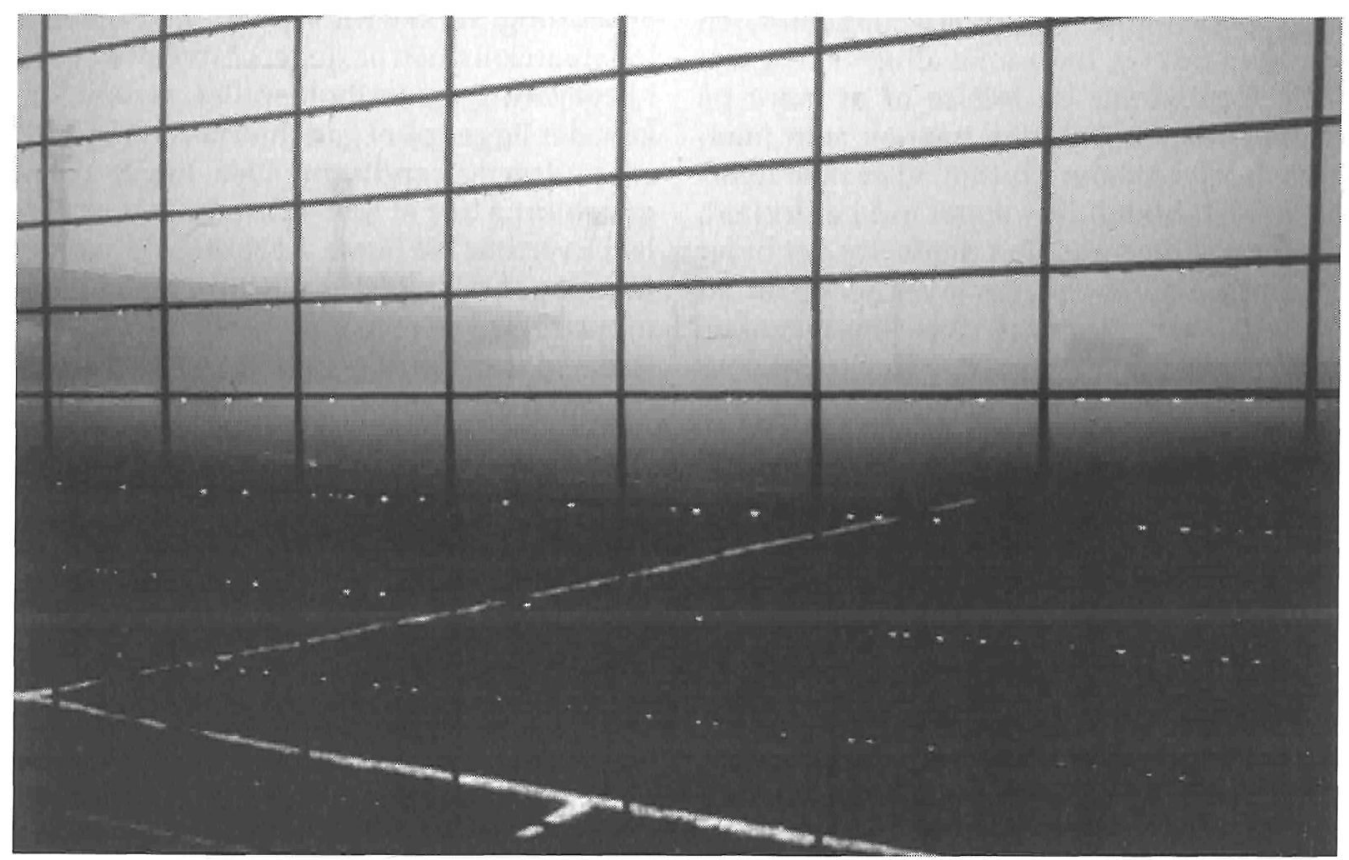

\section{Vejene mellem fodboldarenaerne}

Pludselig må vi bremse meget hårdt op, strømmen af biler er blevet til en massiv blok af jern, der står på gummi. Det er et chok, når vi at standse inden vi torpederer bilen, der står lige foran os? Ja. Derefter bliver vi ramt bagfra? De vinende bremser tier. Vi ånder lettet op, men et nyt spørgsmål trænger sig på, hvad er der sket?. Pludselig er lemlæstelsen og døden tilfældigt så tæt på, at uhyggen udfylder den tomme stilhed.

Ingen bevæger sig. Og vi vedikke, hvad der er sket, det må være noget længere fremme. Den yderste højre bane går langsomt igang, stopper, går igang. Irritationen breder sig uvisheden er foruroligende. Tiden går ude af trit med vore ønsker.

Sirenen fra en ambulance der kommer kørende i fuld fart på viesporet kommer nærmere. Det må være meget langt fremme, der er sket noget, for sirenen kan høres til den forsvinder langt ude i disen. Skyldfølelse over utålmodigheden dæmper uroen. Tågen og regnen er elementerne, der svarer til situationen. Endnu en ambulance, en politibil, endnu en ambulance og endelig en kranvogn og en lastbil der kan transportere flere biler på en gang.

Trafikken begynder langsomt at glide. På den modsatte kørebane kommer den første ambulance kørende uden udrykning. Vi ånder lettet op. Den halve time i bilen der stod stille, spændt fast $\mathrm{i}$ selen låst fast $\mathrm{i}$ blokken af biler var en beklemt oplevelse, som er rar at slippe ud af. Biler er bedst at være i, når de kører. Humøret stiger, men vi får en påmindelse. Ude på vigesporet står seks stærkt beskadiget biler stablet pænt op i rad og række på det store biltransportkøretøj. Vi er på vej mod Liverpool.

\section{Liverpool}

Byen Liverpool er en stor skrotbunke. Jeg har aldrig set noget lignende. En storhed er død, som en drøm der er forsvundet i ligegyldigheden overfor folk som man har udbyttet. Maskinerne er gået i stå, og man har ladet befolkningen blive, hvor de så kan leve fra hånden til munden.

Menneskene er væk og afløst af stemningen - evakuering. Håbløsheden kan ikke længere tilskrives et system, kommunisme eller kapitalisme, liberalisme, socialisme, men tilværelsen - slet og ret. 
Liverpool ligner en forladt slagmark, en møgbeskidt by, hvor man alligevel bag det hele fornemmer en følelse af at være på hjemmebane. Historien hænger som mættede begivenheder i luften, vi er ikke hvorsomhelst. Man bliver suget ind i et forfald, der er ophidsende. En ophidselse der bider på som en tilværelse, der leves her og nu. At være vokset op her må være ledsaget af en uovervindelig håbløshed, alligevel har husene og omgivelserne en charme, som man kan komme til at elske. Byen har noget over sig, som slet ikke findes der hvor der er saneret og menneskene flyttet hen i monotont betonbyggeri, hvor der hverken er venner eller fjender, og alt det nye munder ud i en dræbende kedsomhed.

Vi kører igennem det ene forfaldne slumkvarter efter det andet og gennem en bykerne, der er skåret i stykker af brutale motorveje. Vi kommer forbi biografer, teatre og andre prægtige offentlige bygninger, der peger på en falden skønheds fortid.

Det arkitektoniske grundmønster er godt nok. 2 etagers huse i rækker efter hinanden $i$ et net af labyrintiske gader, der vækker ens nysgerrighed. Det er den flabede gadedrengs hjemmebane. Her kan han gå på opdagelse uden at være under opsyn. Der er et horisontalt lys over bydelen, hvor solen morgen og aften når alle - også når det er overskyet. Her kan man leve altid uden at forlade bydelen. Man er bundet til den del af byen og alle dens uskrevne love. Der er overalt den lokale pub, hvor man selv lægger tonen i det sprog, der bruges. Her er det svært, for ikke at sige umuligt, for fremmede at trænge ind og få besked om, hvad der virkelig foregår. Det er en del af labyrintens hemmelighed. - Her er $800 \mathrm{~m}$ langt væk.

Det er alt, det man fornemmer inden, vi pludselig står konfronteret med Evertons store stadion.

Det står, som det er vokset ud af omgivelserne, men alligevel rodfæstet, som bydelens klub. Her har man bygget efter sit eget hoved uden nogensomhelst er blevet spurgt eller har vovet at blande sig. Stykke for stykkeer dette kæmpe stadion i de mest usle materialer i gråt og blåt vokset op på den anden side af en ensrettet gade. Everton er fællesskabets vokseværk. Bygget op uden vejledning, stykke for stykke i takt med, at lokalpatriotismen er steget så meget til vejrs i begejstring for fodboldspillet, at selv kirken, der ligger på et gadehjørne, er blevet til en undseelig randfigur. Den ligger på et gadehjørne bag et lavt jernstakit der er malet i Evertons blå farve. At stadion i lokalbefolkningens bevidsthed hører til her, demonstreres ved at mange beboere har malet deres døre, vinduer, gerigter og karme, evertonblå.

Her lever ven og fjendskaber, det ses på den graffiti en Liverpool F.C. tilhænger har skrevet på muren "EFC ED SHIT."

Der har været nogen at pisse sit budskab af på de andres enemærker, og det til trods for at Liverpool F.C. er naboklubben. Det viser, hvor tæt man er bundet til det nære by- og lokalområde, når der kan være så meget på kant med dem, der ikke bor længere væk.

I Liverpool findes to stadioner der kan rumme 40.000 tilskuere indenfor en radius af $1 \mathrm{~km}$.

You'll never walk alone

På vej hen til bilen møder vi en ung kvinde, der er på vej ind i en rød bil med Liverpool F. C.s trofæer i bagruden. Vi spørger efter Liverpool F.C.s stadion, hun siger, at vi kan følge efter hende, så vil hun vise vejen.

Fem minutter efter er vi der. Byen her har den samme struktur, som vi lige er kommet fra. Men vi mærker med detsamme, at vi er kommet ind på et andet territorium. Den blå maling er afløst af rød, der nu er smurt på vindueskarme, stakitter, havelåger, porte m.m. Trøstesløsheden er den samme, selvom der her er mere luft mellem stadion og de omkringliggende huse.

Det hellige går igen $\mathrm{i}$ en enormt flot smedejernsport, der står som et smykke med indskriften under klubben logo

You'll never walk alone

Porten til himmerige med erindringen om de efterladte, hvis minde på godt og ondt lever videre i klubbens ånd. At fodboldens himmelske højdepunkter også har haft en pris ses i det monument, der er stillet op ikke langt fra himmeriges port. Mindet om dem der fik en meningsløs død i glædens stund i pokalopgøret på Sheffield Wednesday sta- 

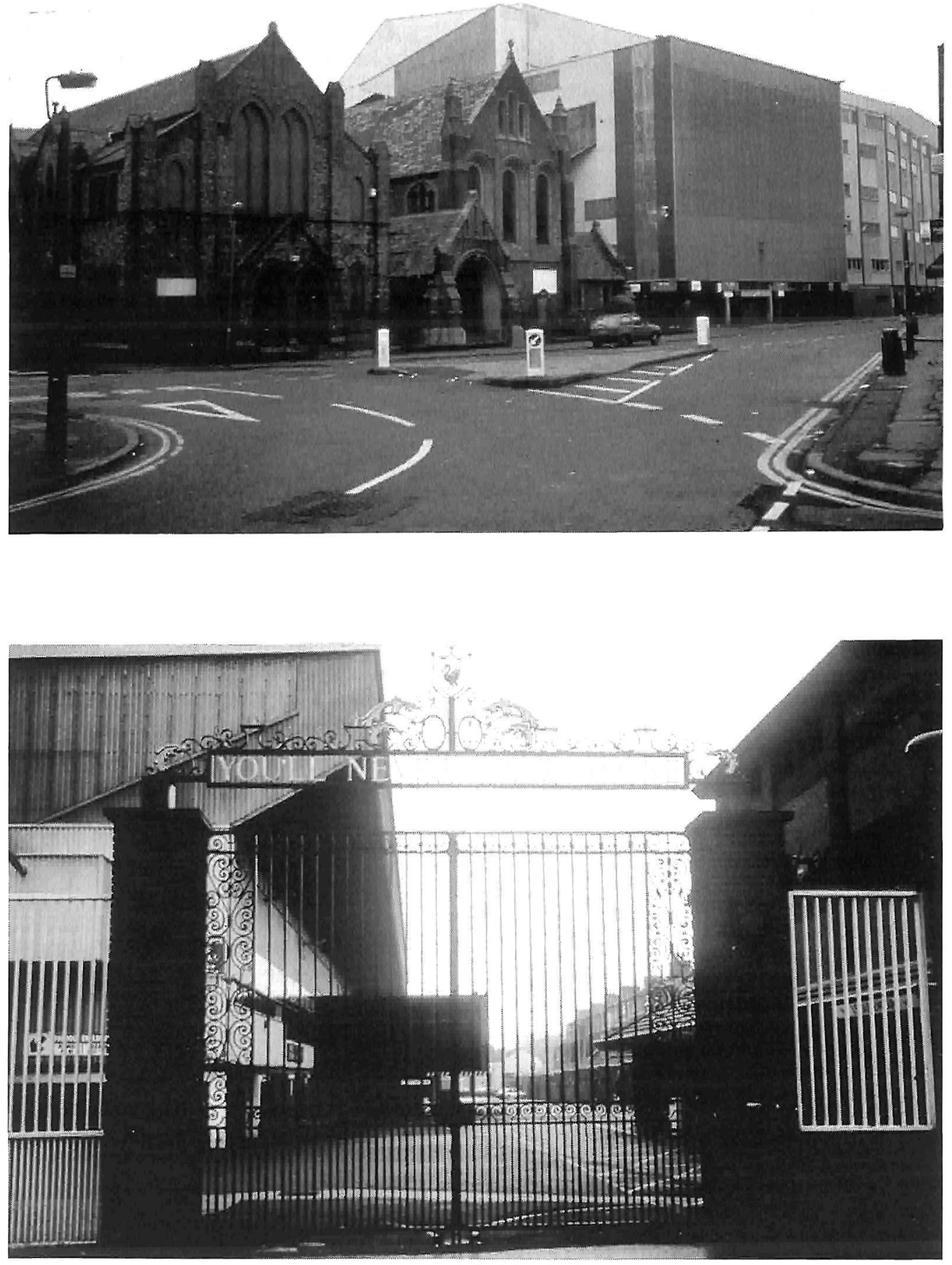
dion. Det viser at storheden ikke kun bærer sejrsrusen, men også sorgen, døden som myte. Et livskraftigt minde, utrolig, direkte og oprigtig, som en sorg fuld af kraft og smerte, som bæres og holdes i live af fællesskabet.

Et virvar af følelser er nærværende. De viser at spillet og legen omkring bolden, kan sætte sindene så meget $\mathrm{i}$ bevægelse, at det kan få uoverskuelige konsekvenser. Løsningen af det uigennemskuelige håbløse rettet mod en selv, selvom ingen ønskede det. De uheldige omstændigheder får en dødelig udgang. Det der skulle have været leg bliver en tragedie, der lever videre som myte. Lever videre i erindringen med samme kraft, som det der er sket på banen.

Her går du aldrig forbi, du er ramt så længe du lever, af porten til Liverpool F. C.'s rige, og rusens dødelige udgang.

\section{Stadions bagside}

Langt borte fra de to porte, på den anden side af det store stadion, løber nogle drenge og spiller fodbold. De er en 6-7 stykker og spiller til måls op ad indgangen til bagsiden af anlægget. Der er noget fint og sart over dem, noget engleagtigt, der hæver dem over de forfaldne huse og skidt og lort, som de løber rundt i. De stikker af fra de trøstesløse og møgbeskidte omgivelser i deres artistiske leg med bolden. De er små bevidste målrettede virtuoser, klædt i mærkevarer. På den vis rager de udover omgivelserne. De har barnets naive kraft og troen på, at fantasierne omkring spillet vil bære dem frem i livet. Ud gennem den tomhed og det forfald de løber rundt i - som set med den voksnes øjne rækker gade op og gade ned. En trøstesløshed, der når helt ud i det centralperspektiv, som ensformigheden og håbløsheden munder ud i. Råheden bundet op på håbløsheden, rusen til stadions natside, stedet hvor euforien henter sin vitalitet. $O g$ når drømmen brister, dette afsindige had, dette indre uvejr som de slæber med sig overalt, hvor de optræder i Europa - som hooligans. Liverpool er en stærk velkomst. Den har sat sine spor, som en enestående fascinerende skræmmende, en ustyrligoplevelse, der dybt nede rummer en poetisk klangbund.
Man forlader aldrig Liverpool uberørt.

\section{Birmingham}

Vi kører den næste dag ud af et net af motorveje nøjagtig magen til dem dagen før. Denne gang kører vi bare en anden vej. Skiltene viser mod Birmingham.

I bilen snakker vi om det samme som i går. Fodboldstadioner, deres omgivelser, udseende, atmosfære, traditionerne, myterne og problemerne omkring dem. De overskygger snakken om glæden ved fodboldspillet og fascinationen ved at gå til og spille fodbold. Det er de sociale konflikter og voldens traumatiske følger, angsten for at den kan bryde ud nårsomhelst, hvorsomhelst, der kommer til at præge organiseringen af sporten. Den har skabt vildrede hos dem, der sætter normen og rammerne omkring spillets fremtid. Og for ikke at komme på glatis i forhold til det sociale kaos, man ikke forstår, har man søgt rationelle og tilsyneladende sikre løsninger.

\section{Et mønsterstadion}

The Bescot Stadion ligger på vejen til Birmingham ved en motorvejssløjfe. Det er et helt nyt stadion til 20.000 tilskuere. Vi drejer fra for at se, hvordan fremtiden tegner sig for fodboldspillet i de mellemstore klubber.

Vejen ned til det nye stadion fører os direkte ud i og gennem et industriområde. Det er de små virksomheder automobil-, maskin - og smedejernsværksteder, gas og vand, varmecentraler og lignende, der er flyttet ud i dette randområde. De er lagt her fordi, de er lidt for store og lidt for grimme til at have liggende i et beboelseskvarter.

Byen som tradition og forudsætning for spillet er væk, vi er på vej mod et forstadsstadion, hvor stedets poesi er en jernhandel - en motorvej på betonpiller og en togstation $\mathrm{i}$ jernbeton.

Vi er på et neutralt sted, hvor menneskene er lette at omringe og holde under opsyn. Det er nemt at følge dem på vej fra ankomsten til afgangen. Bymennesket bliver kørt til et sted, hvor det ikke kan nå at slå rødder, et sted hvor de egentlig ikke hører hjemme og 


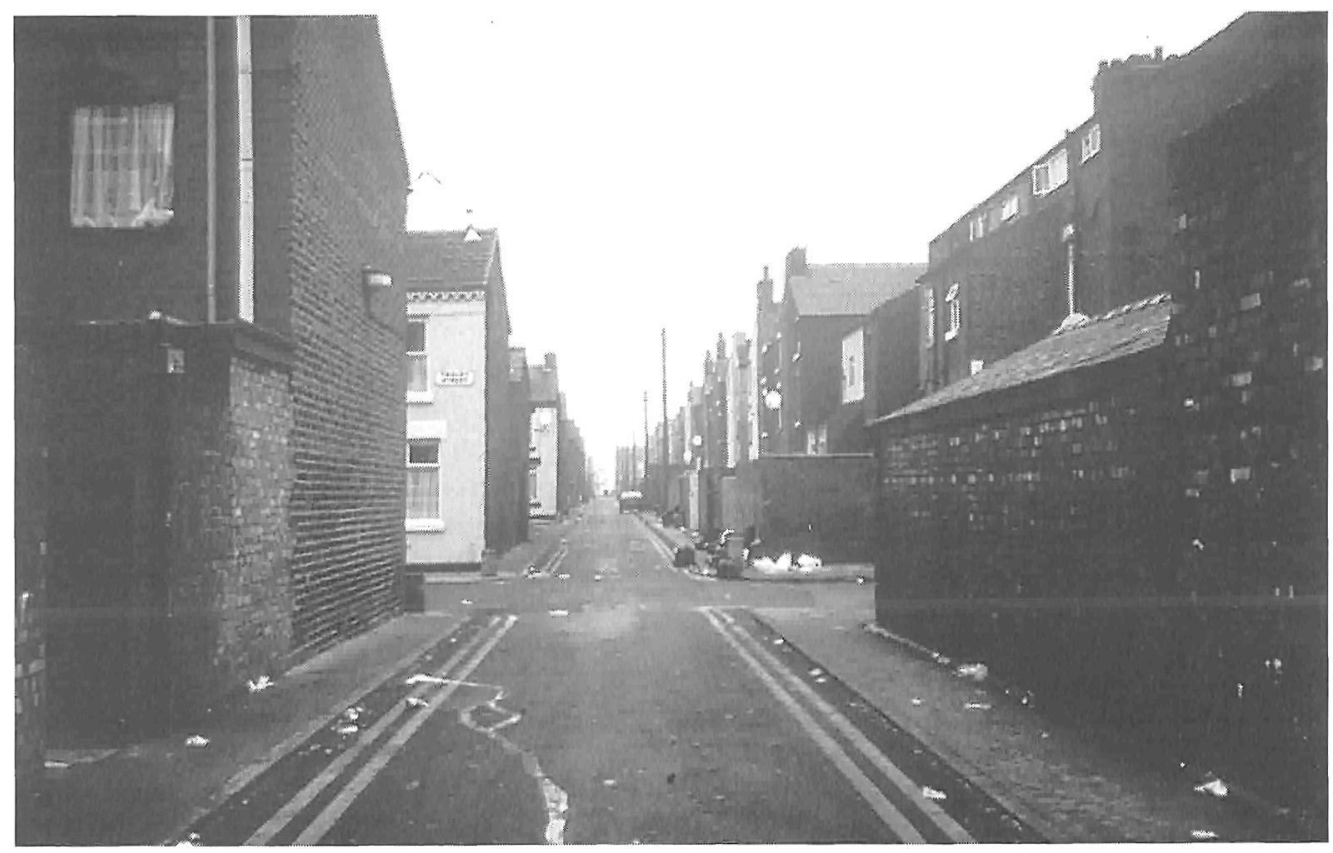

gjort til en hob. Ude- og hjemmebane er stort set ligegyldig. Vi er ingensteder - et ideelt sted for verdensmesterskaberne i firmafodbold. Det er de indtryk som bekræftes jo nærmere vi kommer Bescot stadion .

Når vi står udenfor sluserne ind til banen, mærker man tydeligt, at planlæggernes fantasi og praksis ikke har kredset om legen og lysten omkring fodbolden, men derimod om et fodboldstadionsregulativ, der handler om normeret sikkerhed. Resultatet er en forstad og industrikvartersarkitektur, der ikke har rod i nogen lokale traditioner.

Traditionerne er hængtop bagefter som udsmykning i form af en mindetavle. Indskriften er et stort og adlet navn, som står mellem datoer og andre navne. Der kunne have stået hvad som helst, spillerens spor er blevet til et navn, der hænger som et abstrakt tegn.

Materialerne er lette og kølige, glatte og lette at holde rene. De er nemme at skifte ud, når de bliver slidte, så der ikke kommer spor af brug, der kunne minde om igår.

Det er mindre råt end Crew, det er glat og som sted meget længere væk. Nærheden er blevet mere fjern. Optakten til spillet væk.
Her er horisonten en åben mark. Der er ingen særlige kendetræk. Et sted der hurtigt glemmes, for man er sendt bort fra desteder, hvor livet foregår. Derfor er det for ligetil, at det kan blive virkeligt morsomt. Det er en fodboldbås til 20.000 mennesker udenfor lov og ret, hvor festen og farverne er blevet dæmpet og blevet afløst af meget reglementeret forhold og store master med højlys i periferien. Der er ikke noget centrum, men en nivellering af flader, der kommer til at stå som rette linier, der skal holdes rene

Fra spillernes perspektiv en bane som alle andre. Det må kunne sammenlignes med at spille fodbold i lufthavne, hvor rejsen og oplevelsen er blevet minimeret til den fordel, at man kan komme hurtigt ind, ud og væk. Hvorfor så ikke blive på det samme sted og sende spillet i fjernsynet?

Vi har været på et stadion som er interessant fordi, det viser noget nyt, men det fænger ikke, selvom pladsmanden er glad for, at her spilles der fodbold under ordnede forhold.

Men fodboldspillet er jo i dets oprindelige skikkelse så fascinerende, fordi det er så uforudsigeligt og som naturen svær at styre. Spændingen ligger i forventningen om, at 
alt kan ske. Dette må sikres uden at barnet skylles ud med badevandet.

Så spørgsmålet må være, om vi har været på et fodboldstadion på et sidespor. Pakkeløsnings stadion.

Er der tænkt på alt andet end fodbold. Nye tider tegnes med et sådant stadion, det er en forandring i forhold til fodbold, der viser hvorledes magt og angst bliver bestemmende for, hvorledes man iscenesætter livet omkring fodboldspillet. Styring kontra forståelse går igen. Affekter og følelser, som man ikke ved, hvad man skal stille op med, bliver mødt med fængsels - og fabriksarkitektur.

Herude på åben mark, har man bygget et stadion i materialer som et middelstort industribyggeri. Kort sagt: planlagt på et tilsyneladende tilfældigtsted, hvor man først og fremmest har tænkt på, at her må der ikke ske noget - et typisk præfabrikeret 0-0 stadion.

Vi kører videre med følelsen af at være kørt forbi sporerne af plasticsæder og duften af beton, og smedejern der er galvaniseret

\section{Tilbage til motorvejen til Birmingham}

Byen møder os på samme måde som Liverpool. Vi kører igennem det ene beoelseskvarter efter det andet i samme stil som i Crewe og Liverpool, men Birmingham er anderledes. Dens forfald bæres oppe af et eksotisk skær. Vi kører igennem beboelsesområder, der ligner de andre til forveksling, men alle beboerne er indere. Enkelte engelske familier skimtes i gadebilledet, hvor alle butikkerne og vareudbuddet er præget af den kultur og de sæder og skikke som indvandrerne har bragt med sig. Et farvestrålende indslag fra en fremmed kultur, hvor en gammel er ved at gå i opløsning Pludselig kommer vi til en kæmpe rødstensbygning, der ved første øjekast ligner en banegård fra Viktoriatiden - der står skrevet med store guldbogstaver - Aston Villa.

Aston Villa er storhed - et bygningsværk som vidner om en storborgerlig, ja ligefrem aristokratisk fortid blandt de så- kald te "big five". Det er ihvertfald en anden og mere storslået udstråling end klubberne Everton og Liverpool F.C. lægger for dagen. Det er de fines fodboldklub bygget $i$ en imperialistisk ånd med de dertil hørende undertoner. Det er tilsyneladende storslåede forhold der krakkelerer, for når man går ind på området omkring den gamle hoved tribune konfronteres man med en kolossal betontribune i konkret tresserstil. Den står på tværs af den første, og de af hinanden. Den ligner en tilbygning fra et andet stadion, hvor den af en eller forståelig grund er blevet til overs.

Det er Englands største enkeltstående siddetribune. Den rager op og står, sådan ser det ud fra siden, som skyggen af en stor kasket og skuer udover grønsværen.

Indefra virker den som en gøgeunge, der stemningsmæssigt skubber de andre tribuner af banen.

At spille op imod den må være en ret mærkværdigt; et brølende højhus med og uden vinduer. Horisonten er blevet til en stor beton balkon, et råbende gab uden jordforbindelse. Massen som nærværende publikum er fjernet, derefter samlet som hob, isoleret, og sat udenfor ved at blive lukket oppe og sat på plads. Fodfolket er depoteret hen i en bås for dem selv oven på et firetagers kontorhus, som de selv financierer.

Manden i det fjerne hjørne er løftet op over det hele, og som tilskuer tilintetgjort.

Båndet med very important persons er lagt ind i to etager. En uundgåelig skæevert og årsagen til hele miseren mellem dem der spiller på banen og deres stampublikum. I de to etager der er indrettet til de opvarmede båse med panoramaruder $i$, overvåges spillet og spillernes præstationer. Der bliver noteret, vurderet og kommenteret, i et spil om millioner og hvor dem der skaber spillet ikke ved om de er købt eller solgt. Dem der bærer hele forestillingen - græsrødderne-er for længst gået ud. Den nye horisonts slagskygge slog dem simpelthen ud. Tilbage ligger en skaldet plæne, the beach. Den maser nogle flittige folk med masser af maskiner og grønt grus på at forvandle den til en manege, hvor bolden kan rulle videre. 


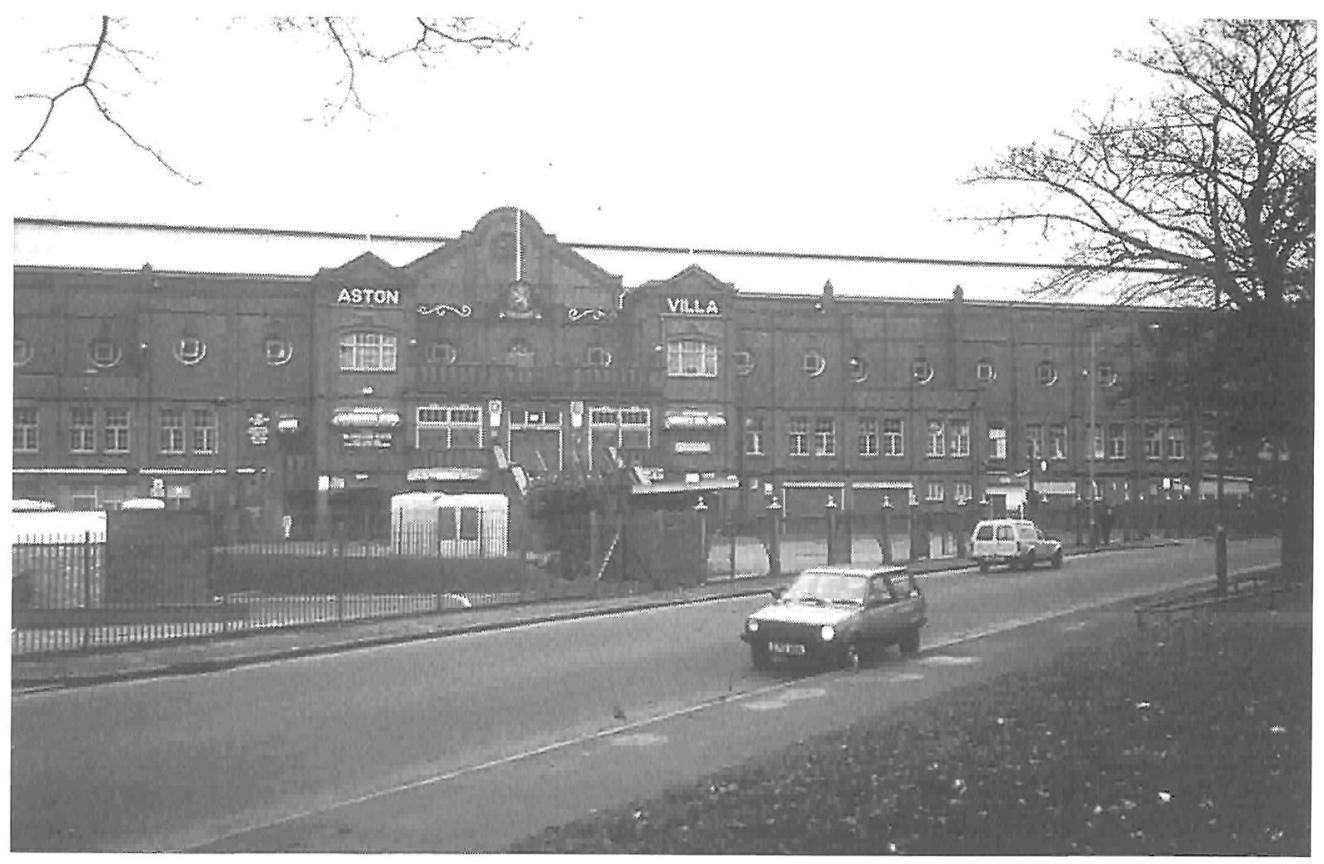

\section{Manchester United}

Om Manchester United siges, at den kunne ligge hvorsomhelst i Europa og alligevel være fodboldklubben over alle andre.

Manchester United er selveste legenden i fodboldspillets historie og symbolet på det ædle spil, når det er bedst.

At Manchester United er noget særligt mærkes allerede, når man kører ind på parkeringspladsen foran hovedindgangen. Selvom stadion er placeret i udkanten af byen $i$ et industrikvarter nær havnen, har klubben skabt sit eget liv omkring sig. Til trods for, at det er en onsdag lige før middag, er der mange aktiviteter på stedet. Der er en velassorteret forretning, hvor man kan købe alt hvad hjertet begærer af souvenirs, beklædningsstykker, sportsudrustninger og mærkevarer osv. der bærer Manchester Uniteds logo til tårnhøje priser. Et ret imponerende udvalg for den pengestærke fan.

Der er udenfor på hoved tribunen et ur og en indskrift, der viser tid og årstal for den forfærdelige flykatastrofe i 1956, hvor Manchester United mistede sin manager, træner og de fleste af de verdensberømte spillere.
Også her hører døden med til myten om den ukronede fodboldklub.

Der er faste rundvisninger for dem, der vil se stadion, sådan som det ser ud, når det er tomt. Man går ind i et cafeteria, som tjener som forhal til klubbens eget museum. Der kan man også købe billetter til de kommende kampe og de daglige ekskursioner.

Vi er kommet udenfor nummer. Men i sagens tjeneste får vi lov at gå ind og se os om. Der er en åben venlig og beredvillig atmosfære omkring stedet. Det kører bare.

Manchester som by er et helt andet centrum end, de andre jeg har set. Gadebilledet i centrum domineres af dyre biler og fine forretninger, akkurat som i Frankfurt a/M i Tyskland. Vi benytter lejligheden til at gå på opdagelse i nogle meget velrenommerede boghandler og i tøj, cafe-og varehus for unge fuld af musikog fantasi. Manchester city er en spændende og tiltrækkende by.

Her kunne jeg umiddelbart godt tænke at slå mig ned.

\section{Sheffield}

Turen til Sheffield starter med en fantastisk køretur ad landevejen henover højderyggen Pennine Chain. Det er øde, trøstesløst, 
men alt tageti betragtning et fantastisk smukt og barskt landskab. Det er helt urørligt. Husene er som vokset ud af den granit, de står på, Vi kommer over ryggen mærker højden i vidderne og ned gennem landsbyerne tyngden $i$ traditionerne, der hverken vil flyttes eller vokse. Jeg har aldrig set noget lignende. Det er en helt anden køretur, end hvor landskabet som panorama giver luft og overblik alt imens bilen vugges op og ned igennem den ene kurve efter den anden, hvor vi til slut bliver slynget op til nye højder med et vidtfavnende udsyn. Solen bryder disen og himlen bliver høj i den tynde klare luft.

\section{Hillsborough}

Forstæderne er smukke, overgangen fra det landskabelige til det urbane landskab er blød og nuanceret. Men det varer ikke ved.

Bykernen er på mange planer skåret op på kryds og tværs. Og den tunge trafik vælter indover bykernen, der dermed kvases. Det er ikke længere landeveje, men motorveje, der fører os ud i forstæderne. Sheffield er en stor by, og vi kører på kryds og tværs i randområder, der veksler mellem industri, kontor, og forretningskvarterer.

Asfalt og beton er de dominerende elementer. Det grønne i landskabet er forsvundet.

Det er ikke ligetil at finde Hillsborough, men det lykkedes. Skiltene viser vej.

Hillsborough er en forstad som andre traditionsrige forstæder fra før anden verdenskrig. Vi møder igen de toetagers rækkehuse, småhandel, værtshuse og butikker med alt hvad man behøver til dagen og vejen. Bydelen lever sin egen lokale tilværelse. Det mærker man, når man går rundt $\mathrm{i}$ gaderne. Den er ikke uden traditioner.

Denne gang kører vi ikke direkte til et stadion, men lægger vejen om til et kontor, hvor en byplanlægger, en pensioneret manager ogen gruppelangtidsledige er beskæftiget med de problemer, der er forbundet med at bo i Hillsborough.

\section{Ulykken}

Der er én opgave, der drager alle og den det meste af arbejdet drejer sig om. Det store fodboldstadion Sheffield Wednesdays, og dets betydning for dem der lever i og omkring Hillsborough.

Kontoret, der var oprettet til at bistå fællesskabet med at løse mange forskellige opgaver ibydelen, opdagede hurtigt, at konflikterne i og omkring det store fodboldstadion overskyggede alle andre. For de lever videre i manges dagligdag, også når kampen forlængst er fløjtet af, og alle er gået hvert til sit.

Det er ikke kun sammenstødene op til og efter kampen, hvor 20 til 30.000 mennesker invaderer Hilsborough, som skal afvikles. Der findes et trauma som stikker dybere. Et der ikke kan ses, når man kører forbi og solen skinner, og alt synes at være intakt. Det kommer først frem, når man kommer på talefod med dem, der lever i Hillsborough.

Ved en særlig lejlighed går massen i en tilspidset situation amok. Alle og enhver vil undgå det, men alle til hobe er sat ud af spillet. Det der sker præger fremover, hver dag, alle menneskers syn på sig selv.

Katastrofen fra april 1989, hvor 95 mennesker (næsten alle Liverpool fans) blev mast ihjel ved The Leppings Lane end of the ground kort før FA cup finalen mellem Liverpool og Nottingham forrest, har sat pinefulde spor i de overlevendes erindring.

Man føler sig skyldig. Kunne det have været undgået, spørger mange sig selv. Andre plages af dårlig samvittighed over at de har solgt øl og andet til Liverpool tilhængerne og på den måde opholdt dem til kort før kampen.

Borgerne i Hillsborough har taget skylden for katastrofen på sig - og den næres ved, at de bliver stigmatiseret af dem, der bor udenfor. Dødsulykken er blevet til belastning for alle beboerne i Hillsborrough, som er ubehageligt at leve med. Et skisma som beboerne bærer - og som medarbejderne på kontoret for fællesskabets ve og vel vil råde bod på ved forskellige planlagte foranstaltninger. F.eks. ved at anlægge en mindepark for ofrene fra Leppings Lane end of the ground. Forsøge at få en dialog igang mellem borgerne, myndighederne og klubben, så de værste gener kan undgås og for alt $\mathrm{i}$ verden en ny katastrofe. 
Hensigten er, at det kollektive selvbillede og image skal vendes, så de værdier der kendetegnede stedet før ulykken bliver så toneangivende, at det igen bliver acceptabelt at bo i Hillsborough.

Poul Weston og hans stab arbejder med en entusiasme der er smittende på opgaven. På kontoret der er meget spartansk indrettet, har man en enestående samling af dokumenter, artikler og andet materiale fra hele landet. Et yderst spændende kildemateriale for alle der er berørt af konflikterne omkring de store fodboldstadioner.

\section{Sheffield Wednesday}

Der er et godt stykke at gå inden vi kommer til Sheffield Wednesdays stadion, hvor vi har en aftale om at blive vist rundt. Denne gang får vi lejlighed til at opleve klubben indefra set fra deres synsvinkel.

Der er lys og luft over forstaden. Solen skinner, der er en levende trafik og gadelivet blomstre. Stadion ligger oppe på et højdedrag. Man kommer til det ved at gå igennem et grønt parkområde, hvor man passerer en bæk og et hegn af piletræer - og så er man der. Man kan fornemme, at det er et stadion, der har ligget her meget længe.

Vi bliver lukket ind af døren for players og officials, og passerer på vejen en spiller og hans drømmebil. Vi træder ind i en lang gang i en verden af i går. Omklædningsrummene ser ud som de har set ud siden de blev bygget. Vaskeriet ligeså. Kvinden der paser det, må have været der i umindelige tider. Det eneste der er nyt er maskinerne. Omklædningsforholdene er primitive. De tre brusere er af den helt traditionelle type; to haner, og en bredspreder ovenfra og ned. Fællesbadet er tømt for vand og benyttes ikke mere, grunden er - risikoen, for at spillerne kunne blive smittet med AIDS, hvis de badede sammen.

Støvlerummet er en perlerække af vidt forskellige typer af fodboldstøvler. De fleste spillere har fire sæt hængende, så de er rustet mod alt slags vejr og grønsværens skiftende luner.

Inden vi går ud gennem spillergangen kommer, vi til hoved tribunens foyer. Den er fyldt med bannere, pokaler og andre hædersbevisninger. Landspokalen bliver hentet frem. Der skal ikke herske tvivl om, at Sheffield Wednesday er med helt fremme og blander sig med the big five.

Stadion åbner sig for spillerne som en velproportioneret hjemmebane. Her har man lyst til at gå ud og kæmpe for sin klub. Der er lys og luft i hjørnerne. Størrelsesforholdene harmoniske og lydbilledet opløftende. Ligegyldigt hvor man går, står eller sidder er man på bølgelængde med den grønne plæne.Så samspillet mellem spillere og publikum er hjemme.

Når man går rundt $\mathrm{i}$ dette stadion, er der intet der virker faretruende og kan henlede ens tanker på en dødsulykke. Derfor får beretningen om katastrofen noget makabert, uvirkeligt, uforståeligt og meningsløst over sig.

Sporene er slettet. Hegnet hvor de blev mast til døde er pillet ned. Navnet på tribunen skiftet ud. Stedet hedder nu Presto West Stand. The Lepping Lane end of the ground findes aldrig mere.

\section{Et levende modspil}

En anden tribune, der står bag målet for en klubs tro hjemmepublikum er den på Sheffield Wednesdays stadion. Der lever græsrødderne i bedste velgående. Her på Englands mest rummelige tribune, for dem der helst vil stå op. Der kan være 25.000 fodboldfans. Og det har der været i mange mange år, uden at nogen er kommet alvorligt til skade.

Her står vi side om side. Oppe og nede, men bag ved målet. Forbundet med hinanden i et nærvær, de selv lægger krop til - og tæt på det, der foregår. Her kan man gå frem og tilbage og mødes i den orden, der passer til lejligheden. Det er en scene, der hverken rager op eller ned, men holder sammen på helheden. Så bagfra er en god opbakning, hvor 25.000 er en jublende og hujende masse, der når det går godt, får det hele til at gå op i en højere helhed, fuld af lyst, sang og eufori - kort sagt katarsis. Det der sker, kan blive en god dag, hvor det spil der bølger frem mellem hjemmeholdet og deres fans, gør det til en levende forestilling. 


\section{The Don Vally stadium}

The Don Vally stadium built for the wold students game in 1990 er et andet mønstereksempel på hvordan et stadion skal være fremover for at undgå fortidens misere.

Det ligger for sig selv nær en motorvej i et industriområde - i dette tilfælde udenfor Sheffield.

Angsten for sammenstød, vold og katastrofer lurer overalt hvor menneskers handlinger og følelser ikke kan kalkuleres. Og optøjerne og sammenstødene kaster et ubehageligt lys på de ansvarlige myndigheder, det rammer.

Det glatte højteknologiske multifunktionelle sportsanlæg, der ligger et vilkårligt sted ude i fremtiden, tegner sig som en glat og tilforladelig løsning for mange lokale og dermed nationale konflikter. Det støder ingen, der bor i byen. Det svæver over alle traditioner. Det er bygget efter alle kunstens regler i en teknik, som ikke kræver boldbehandling. Målet er målene dvs. måleenhederne minutter, sekunder, tiendedele - og millisekunder, meter, centimeter, millimeter. Og det er størrelser, som er svære at se med det blotte øje oppe fra tilskuerpladserne. Den virkelige præstation kan først bedømmes, når den bliver meddelt over højttaleranlægget eller dukker op på lystavlen.

Benyttes sportsarenaen til at spille fodbold i foregår spillet på den anden side af centersbaner, springgrave og andre omkredsende eller afstandskrævende enheder, der alle tjener til at øge distancen mellem spillere og publikum - der under disse omstaendigheder bliver til aktører og tilskuere.

Debliver skilt ad og falder fra hinanden når bygningskroppen bliver til teknologiseret friluftsliv, hvor man kunne forestille sig, at banen var rullet ind over og lagt ovenpå et rektangulært svømmebassin.

At man er langt fra hinanden spiller ingen rolle, for horisonten er som skabt for atletikudøvere. Det er et sportsstudie, der betoner enkeltpræstationen fremfor sammenhængen, der falder udenfor og fra hinanden i tid og rum. Tidens spor klæber ikke til lette former, der kan udskiftes efter behag, som reservedele i et industrianlæg.
Vi er havnet på neutral grund, et sted hvor fjernsynet kan transmitteres. Sende det, der sker fejlfrit ud i æteren til hele kloden. Så alle kan sidde i de små hjem verden over foran fjernsynsskærmen og få indtrykket af, at tingene fungerer, som de skal. De er tæt på de begivenheder der foregår lige nu, langt væk, her og nu. Tilsyneladende har de overvundet distancen. Det fremkalder følelsen at have magt over tingene. De ser med overalt uden at bevæge sig en tomme. Det forøger sådan set sikkerheden over alt.

\section{Det levende stadion}

Stoke City hedder klubben. Stoke hedder byen. Det er lørdag eftermiddag og vi giver os på vej til kampen mellem Stoke City og Dem der kommer udefra ankommer med tog, bus eller er i bil. Parkerer man i udkanten af byen og går til stadion til fods, mærker man hvordan byen vågner og bliver nærværende op til kampen på Stoke Citys' stadion. Overalt starter små grupper i en klynge en bevægelse, der bliver til en strøm af mennesker, der alle går efter det samme mål. Byen bliver til en levende organisme, der vokser sammen til en helhed, en enhed, man bliver både opstemt og pirret af at gå med i. Man vokser i strømmen uden at forsvinde i fællesskabet, men løftes af de andre uden at kende dem, der er med til at skabe den fornøjelse, det er at gå igennem gaderne, der med strømmen af mennesker tilvejebringer den atmosfære, som forventningens glæde kaster af sig. Intensiteten stiger jo nærmere vi kommer. Vi møder de fans, som bærer klubbens mærkevare. Rød hvide farver kommer til syne som hatte, trøjer og bannere og bliver den fremtoning, der binder den der føler, at de hører til i Stoke City sammen

Programsælgerne står på gadehjørnerne og forsyner dem, der vil have det, med klubbens blad eller dagens kommenterede holdopstilling. Der er boder og pølsevogne, hvor man kan købe kaffe og andet godt, der luner i landskabet en lørdag eftermiddag i januar. De står opmarcheret foran stadion, der lyser som en kæmpe katedral. Strømmen af mennesker stopper og står nu som lange rækker, der venter på at blive 


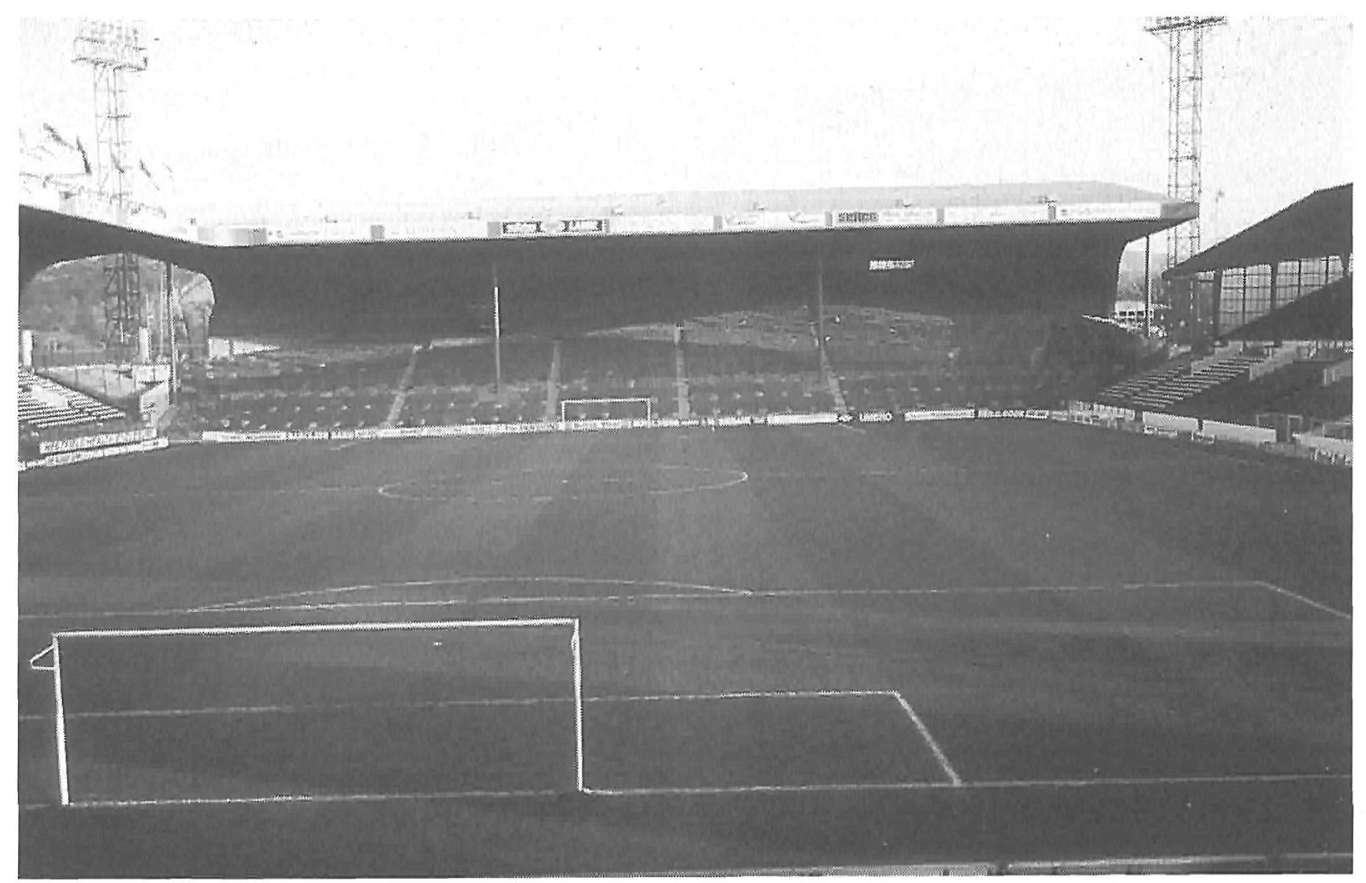

sluset ind gennem nogle meget smalle porte. Man fornemmer, at vi er mange; strømmen er blevet til en masse mennesker. Det er trangt og ubehageligt at blive sluset ind, men stadions indre åbner sig med en flot grøn plæne, der står og lyser som en scene, der bader i projektørlys. Langsiden med stå pladser fyldes langsomt af dem der kommer ind. Det er en befriende oplevelse at blive til os i den størrelsesorden. Dem der kender hinanden, finder deres vante pladser. Der er en summen af velvære og forventningens glæde breder sig. Bag målene i hver sin ende af banen er gæsterne og de virkelige fans ved at gå i stilling. Kampen kan gå igang. Alt er på plads, når spillerne til alles jubel løber ind på banen.

Deres ankomst på arenaen sætter en bevægelse igang, der bringer spillerne og deres publikum, dem der er for og imod hinanden, sammen $\mathrm{i}$ en uadskillelig og uforudsigelig enhed. En syntese der berører alle. Når fløjten lyder flyder alles jeg og vi sammen, så alle med et er langt væk hjemmefra - udleveret til det spil der foregår her og nu. Vi bliver revet med og lærer den opløsning og det løft at kende som kommer, når jeg'et slipper kontrollen og bliver et sprudlende vi - et massefænomen. Og det uanset alder og stand, alle mærker på deres egen krop, at de lever og tilhører stedet og dets traditioner.

Forudsætningen sammensmeltningen er et utroligt kompliceret mellemværende, hvor alle sanserne med et er spillevende og oppe at svinge på hele følelsesregisteret. Vi er uden døre, og tripper rundt i vejrliget. $\mathrm{Vi}$ er tæt på græsset, der dufter og går helt derop, hvor vi står. Vi er så tæt hinanden, at vi kan mærke svingningerne fra de andre tribuner. Kun dem der sidder over og bag os er langt væk, for dem kan vi ikkese. Vi bliver våde og fryser, bryder alligevel ud i sang, oplever glæden og euforien, når det går godt for dem, vi er med på banen. For i næste øjeblik når det går skidt for de samme at gå igennem et følelsesmæssigt vekselbad, hvor man sporer kulden, raseriet, modløs- og rastløsheden, for senere måske igen blive revet med i en jubel, der løfter en til en velvære, der er orgastisk. Om vi lander oppe eller nede ved ingen, før fløjten lyder og alle må gå hver til sit og tilbage til den virkelighed som præger den enkeltes daglige tilværelse. 


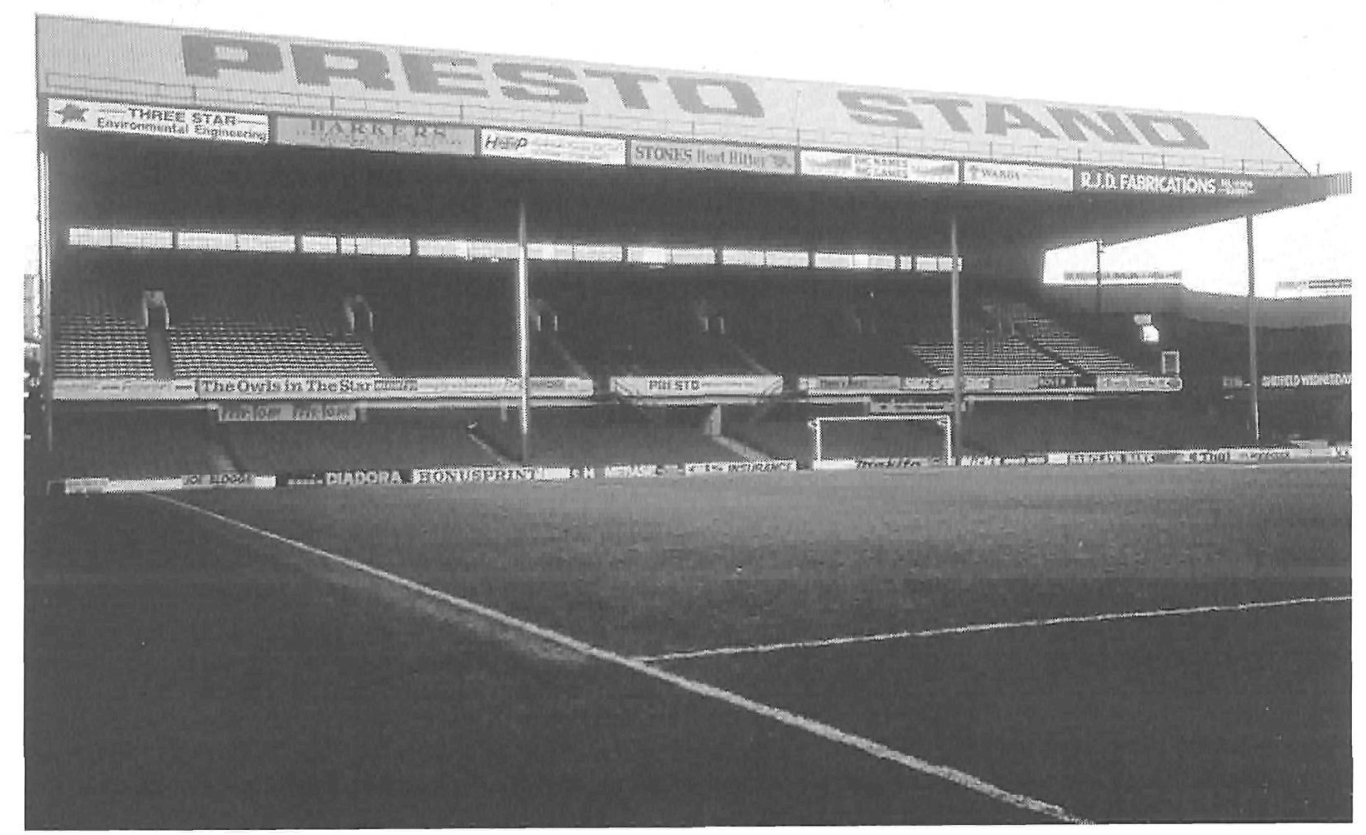

\section{Vejen tilbage og hjem}

Stocke City blev dagens vinder. Vi forlader stadion som venner, der skal tage afsked fra et inspirerende togt. Det var det sidste stadion i denne omgang.

Om aftenen er der en lille sammenkomst hos Ruth og John Bale. De har inviteret deres naboer Dorothy og Allan, et yngre ægtepar hos hvem vi først på ugen var indbudt til en overdådig middag. Stemningen stiger på en anden måde end på banen. Den informelle snak flyder let og ubesværet som i gode venners selskab. Vi griner meget og har det sjovt. På et tidspunkt hvor selskabet ligger i det rigtige leje udbryder Ruth:

John, you know that this is the first time Soren has been to England. Why on earth did you show him only the terrible places when there are so many beautiful places around? You never brought me to these places before so I don't know why you had to show them to a visitor.

Fodbold er åbenbart ikke alt i England, men det er en anden historie.

Næste morgen bliver jeg kørt til lufthavnen i Manchester. 11/2 time senere, dansk tid, lander jeg i København. Selvom jeg hele ugen havde kørt i den forkerte side, følte jeg mig ikke fremmed. Det var som om, der havde været nogen der før mig, som jeg kendte.

\section{Grund til bekymring eller grund til appel (John Bale)}

Billederne på de foregående sider har ikke blot fremkaldtstorslåede oplevelser afSTED, men også visualiseret den britiske fodbolds landskabshistorie.

De minder os om spillets rødder, om det bymiljø i hvilket det voksede op, om sportskatedralernes struktur og deres halvreligiøse kvaliteter og, efter traumet i Hillsborough, om scenarierne for den fagre nye verden for "folkets spil".

I denne korte afslutning vil jeg relatere disse visuelle udtryk for britisk fodbold til nogle hovedtendenser, som kulminerede i Taylor-rapporten om Hillsborough katastrofen og dennes forslag til et nyt landkort for den nationale sport.

Men indledningsvis skal det bemærkes, at billederne i denne bog ikke præsenteres af en hvilken som helst fremmed, men af en dansk gæst - fra et lille land hvis fodboldstadioner ofte ligger i sunde forstæder eller 


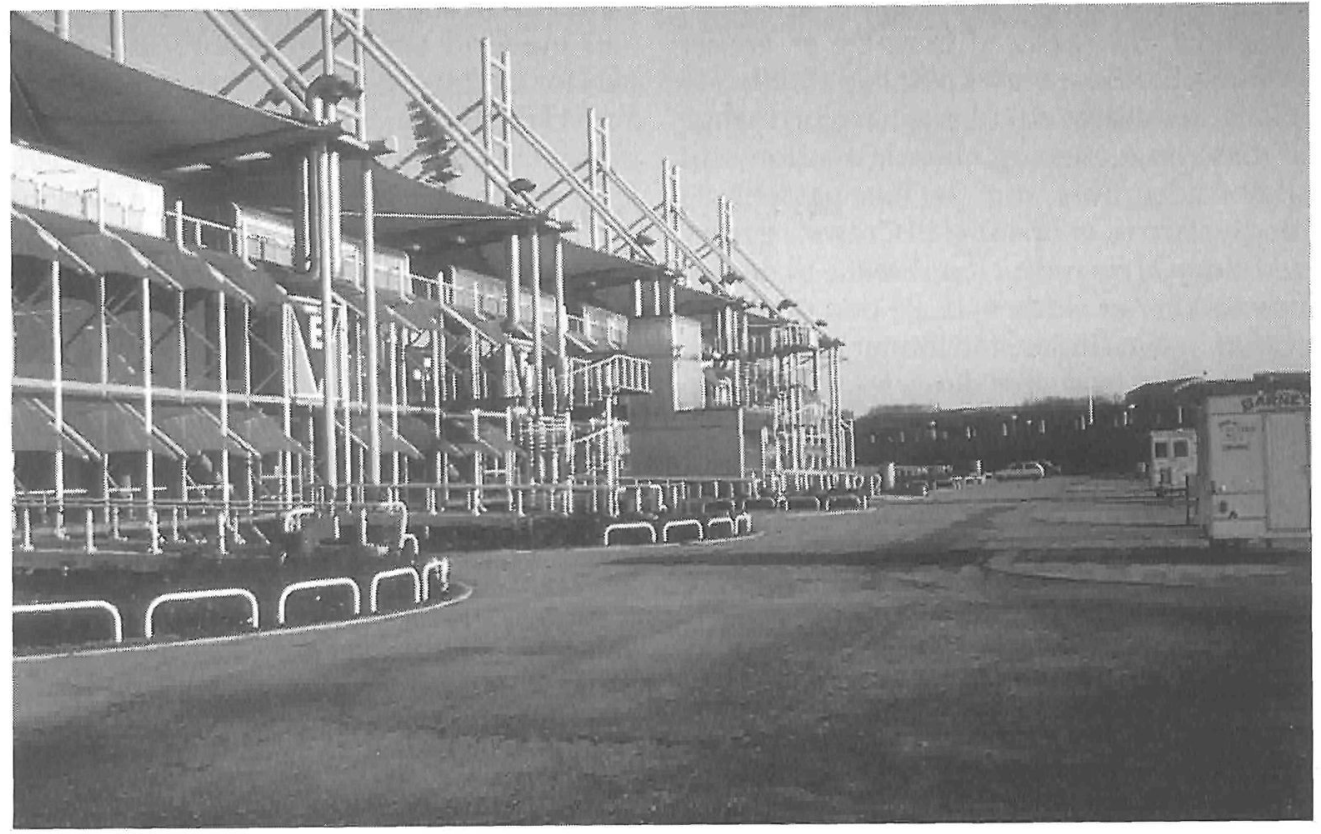

omgivet af parker eller skove. Ved 1. divisionskampe i Danmark er der få, hvis overhovedet nogen spor af politi; de respektive holds tilhængere rejser $\mathrm{i}$ al venskabelighed med samme tog til kampene; her er det som oftest ikke nødvendigt at holde grupperne adskilt. Dansk fodbold er ofte sjov, og deres fans kaldes ",roligans" (,rolig“ er det danske ord for fredelig), ikke hooligans. Set med danske øjne er den engelske fodboldkulturs indflydelse måske blevet overdrevet, hvilket måske afspejler sig i de foregående siders billedsprog.

Det er også vigtigt at understrege, at dette danske syn på engelsk fodbold er begrænset til nogle få af sportens centrale kultursteder. Sheffield var det nordligste punkt og Birmingham det sydligste på vore rejser. Vi besøgte ikke Bournemouth, Wimbledon, Oxford, Ipswich, Norwich, Cambridge eller Brighton, alle hjemsteder for kend te fodboldklubber, hvor baneanlæggene har større lighed med Akacie Allé end med Gasværksvej.

Ved at koncentrere os om Nord- og Midtengland (selv om nogen måske ville mene, at vi ikke har besøgt hjertet i det nordøstlige) har vi været istand til at indfange duften på desteder, hvor fodboldkulturen efter al sandsynlighed vil undergå de største forandringer som lovet (eller truet med) i Taylors rapport.

Fodboldens historie afspejles ved begyndelsen af Søren Nagøls besøg - på en mark på landet. Det som i dag foregår i utallige landsbyer i England, minder om den moderne engelske fodbolds barndom. En midlertidig bane på en bondes mark, uden tribuner, får i stedet for maskiner til at holde græsset nede, få tilskuere og amatørspillere; dette var fodboldspillets kendetegn efter dets tidlige systematisering som en moderne sportsgren. På et sted og på et tidspunkt, som ikke er registreret i fodboldspillets historieskrivning, mente nogle at spillet - på et vist færdighedsniveau - var underholdende nok til, at man kunne forlange penge i entre. Rundt omkring i byerne, hvor folk samledes til almindelig underholdning, begyndte man at bygge specielle steder, hvor det var muligt at se fodbold. Der blev anlagt fodboldbaner (ikke stadioner i England - i det mindste ikke før i 1980'erne), ofte som udvidelser af parker eller friluftsområder og ofte mellem boligområder. Dengang krævedes ikke planlægningsgodkendelse. I Crewe og lignende ste- 
der er fodboldanlæggene en del af byen ikke en forlængelse af den. De er vokset frem og har ikke været planlagt. Skiftende lokaleog statslige cirkulærer har gjort mange af disse hyggelige og elskede stadioner til triste steder. Bure, som slet ikke passer ind $\mathrm{i}$ omgivelserne, er opstillet til Crewe's gæster ved siden af de rødmalede bænke til de, der foretrækker at sidde ned. På den modsatte side af banen findes ståtribuner til de, som i dag kraftigt forsvarer deres ret til at stå op og deltage i dialogen og drilleriet - endog med deltagerne på banen.

På trods af forbedringer forbliver faciliteterne basale. Britisk fodbold har altid været et mandespil, og de få indrømmelser til kvinderne afspejler på en patetisk måde ambitionerne hos de personer, der ønsker at gøre sporten til en form for "familieunderholdning". Men hvordan vil man kunne underholde en familie, der står bag det tykke jerngitter af en fængselsmur, der omslutter Crewes "gæster"?

Det er i lige så høj grad disse militære forsvarsværkers afstikkende karakter som deres døende struktur, der gør dem til så dystre kulisser. På en fugtig, søndag vintermorgen, søndagen efter ritualet lørdag eftermiddag, ser det ud som om banen på Gresty Road græder.

I byer større end Crewe tiltrak spillet mange flere mennesker og krævede opførelsen af meget større baneanlæg. Også disse er vokset frem, og på trods af at de er gigantiske stålkonstruktioner, ligner de til en vis grad katedraler, ligesom på Grodison Park, Everton F.C.'s hjemmebane, hvor konstruktionen dominerer rækkehusene, der ligger i skyggen på den anden side af vejen, men som stadig afspejler det arbejderklasse-landskab, i hvilket sportsgrenen fra Cambridge University og de privateskoler slog så stærke rødder.

Nogle større industribyer - som Liverpool - kunne have og har faktisk to store klubber, som of te er meget stolte over deres eget omdømme og villige til at rakke ned på deres rivaler ved den mindste anledning.

På Anfield, hjemmebane for Evertons naboer Liverpool FC, synes stedets religiøse karakter at overgå enhver sammenligning.
Denne stolte klub har sin Shankly Gate med dets moderne smedejernssalme, mindestenen for de Liverpool-tilhængere, som omkom i Hillsborough og de følgesvende, som tilbeder internationalespillere som Ian Rush, John Barnes og Jan Mølby fra de næsten dickensianske gader i kvarteret.

En oplevelse af sted stammer ikke kun fra en banes religiøse symbolik, men også fra dets hjemmelignende kvaliteter. I Birmingham er Aston Villa et prægtigt hjem fra århundredeskiftet, hvor de røde mursten fra Victoria-tiden stadig dominerer de mere brutale nye tribuner og de mangelfulde baner, hvor Aston Villa's hjemmekampe spilles. Fra stolte baner som denne, og fra Manchester United's Old Trafford har en betydelig del af tilhængerne altid foretrukket siddepladser; bedre og mere sterilt plastik sammenlignet med Crewe's jævne træsæder vil nogle måske tænke. I Hillsborough, Sheffield, derimod vidner det største antal ståpladser i britisk fodbold i den ene ende af banen, om den britiske hobs forkærlighed for kollektive ritualer - svajen, råben, sang, skældsord - måske en rest af det Rabelaisianske karneval i det 20. århundrede.

Tragedien i Hillsborough den 15. april 1989 gav det endelige stød til at skubbe den rå, arbejdsmands-fodbold ind i det 21 . århundrede og gøre den til en form for familieunderholdning. Dette afspejler sig allerede i Hillsboroughs arkitektur; ståtribunerne vil forsvinde; således har den rekonstruerede del af banen (Lepping's Lane), hvor tragedien skete, allerede en ny personlighed, et nyt ansigt, i et forsøg på at fjerne rædslen over de 95 dødsfald, som fand t sted på de tidligere ståtribuner bag målet. Heldigvis er der stadig minder om ældre (og bedre?) tider - det berømte ur og træsæderne. Under tribunerne - og her er Hillsborough typisk - synes tiden at have stået stille, og havde det ikke været for reklamerne for Adidas, Puma, Nike og Acsis kunne vi lige så godt være tilbage i 1930'erne.

Renovering af de eksisterende stadioner er en af måderne, hvorpå spillet vil forandre sig frem til år 2000. Stole vil erstatte ståtribuner, kvinder og børn vil erstatte mænd, og piger vil erstatte drenge. Ligesom i Amerika vil familierne se fodbold og reagere på 
„markedskræfterne", dvs. hver enkelt har en siddeplads, hver enkelt er en del af et kræsent publikum - ikke fanatikere, der følger deres hold gennem tykt og tyndt. Det vil være et ikke-sexistisk familieshow, som erstatter det højst traditionelle kønsopdelte landskab præget af arbejderklasse-maskulinitet. Men stedet vil stadig være det samme og det vil stadig være hjem for de, som fortsat kommer for at se "deres" hold.

Et andet scenarie er nu også ved at tegne sig på de britiske sportsgrenes landkort; et billede med et helt nye stadion, der ikke er placeret i et boligkvarter, men blandt bygninger med grossist-, lager- eller let industrivirksomhed. Ofte i et forstadskvarter. Bemærk venligst, at der (ligesom på Bacton stadion) ikke er tale om "baner" i Walsall i Midtvestengland; det er anlagt ved en motorvejsafkørsel med sin egen jernbanestation og med masser af parkeringspladser. Ordet "stadion" afspejler et forsøg på at opgradere stedets image, men på afstand kunne det være en lagerbygning eller en fabrik. I designsproget kunne det at være en maskine, som producerer fodboldkampe, kold, klinisk og med skarpe hjørner. Måske er de røde plastik-vippe-sæder på betongulvene komfortable (eller er de?), men ville fodbold være lige så fornøjelig en oplevelse for en traditionel tilhænger sådan et sted? Hvor meget er tabt i takt med de fremskridt, som sådanne baner antyder?

Walsall stadion er en fodboldbane - i lighed med de fleste andre fodboldbaner i Storbritannien er det et specialiseret landskab, som er til ringe nytte for andre formål. Men fodboldsportens fremtid kunne også ligge $\mathrm{i}$ et stadion, der er egnet til mange formål, med en syntetisk løbebane uden om en fodboldbane med plastikplæne, der hver især kan danne ramme om en række aktiviteter udover løb og fodbold. Banen på Don Valley stadion er ikke af plastik, dette stadion (bemærk igen ordskiftet) er ikke en ligafoldboldbane, da den ejes af kommunen, og de to store Sheffieldklubber har ikke vist den store interesse for dette stadion. Men det er symbol på det som vil komme, hvis Taylor-rapportens anbefalinger bliver virkeliggjort.
Stadionet er alsidigt; der er siddepladser til alle tilskuere, der er bevogtning overalt; der er gode parkeringsmuligheder, det er placeret udenfor den trange bymidte, og det kunne være fælles bane for begge Sheffieldklubber, United og Wednesday. Forskellige stordriftsfordele kunne opnås ved brugen af et sådant stadion. Med sit (post)moderne rørdesign adskiller det sig væsentligt fra de trøstesløse baner fra århundredskiftet, som vi startede vores tur med at se på. Det er symbol på det som kommer.

Men Sheffield-klubberne ønsker ikke at benytte det. Paradoksalt nok reagerer de mod rationalismen og foretrækker de gamle baner i deres historiskeomgivelser. Nostalgi, tradition, den industrielle billedverden og fornemmelser af sted viser sig at være stærkere end det moderne, men mindre personlige, high-tech super-stadion. Her distanceres tilhængerne fra deres helte af et "cordon sanitaire"; den kolde cement symboliserer stadionets kliniske karakter; de nummererede sæder gør menneskene til ting.

I de kommende år vil folk fortsætte med at besøge de gamle baner i byerne, som for eksempel Victoria Ground (aldrig et stadion) iStoke-on-Trent. Stoke City kunne, ligesom Sheffield Wednesday, begynde at overveje at dele bane med naboligaklubben, Port Vale, men modvilligheden herimod afspejler den engelske nationalsports næsten unikke kultur; ind til videre synes fremskridtets logik ikke at have kunnet dæmpe den ejerfornemmelse, som tilhængerne har over deres baner.

Oversættelse Lene Mortensen

\section{Litteratur:}

Eric Dunning, Patrick Murphy, John Williams: The roots of football hooliganism. London Routledge 1988.

Steve Redhead: Sing when you're winning. London Pluto Press 1987.

John Bale: Sport, space and the city. London Routledge 1992.

John William, Steve Wagg: British football and social change. Leicester University Press 1991. 
